Abstracta Iranica Abstracta Iranica

Revue bibliographique pour le domaine irano-aryen

Volume 29 | 2008

Comptes rendus des publications de 2006

\title{
«From Mission to Profession: Journalism in Iran ". Iranian Studies, volume 39, number 1, March 2006, pp. 1-28
}

Marcus Michaelsen

\section{(2) OpenEdition Journals}

Édition électronique

URL : http://journals.openedition.org/abstractairanica/32662

DOI : 10.4000/abstractairanica.32662

ISSN : 1961-960X

Éditeur :

CNRS (UMR 7528 Mondes iraniens et indiens), Éditions de l'IFRI

\section{Édition imprimée}

Date de publication : 15 mai 2008

ISSN : 0240-8910

Référence électronique

Marcus Michaelsen, « « From Mission to Profession: Journalism in Iran ». Iranian Studies, volume 39, number 1, March 2006, pp. 1-28», Abstracta Iranica [En ligne], Volume 29 | 2008, document 384, mis en ligne le 15 septembre 2008, consulté le 26 septembre 2020. URL : http://journals.openedition.org/ abstractairanica/32662 ; DOI : https://doi.org/10.4000/abstractairanica.32662

Ce document a été généré automatiquement le 26 septembre 2020.

Tous droits réservés 


\title{
« From Mission to Profession:
}

\section{Journalism in Iran ». Iranian Studies, volume 39, number 1, March 2006, pp. 1-28}

\author{
Marcus Michaelsen
}

Cet article donne un historique général de la presse en République islamique dès la révolution jusqu'à nos jours. Il apporte de nombreuses informations quant aux différents titres de presse (pour la plupart déjà disparus), au tirage et au nombre de journalistes professionnels, documentant ainsi le chemin ardu que le journalisme d'imprimés a pris ces dernières décennies. Une idée intéressante est ici d'examiner les festivals de presse qui ont eu lieu successivement depuis 1991. Les prix accordés ainsi que les propos de participants reflètent les progrès mais aussi les difficultés de la profession journalistique à travers les années. En même temps, la revue de divers commentaires du Guide Khamenei montre les attentes et limites du système politique vis-à-vis de ses médias. Bien qu'on assiste, après 1995, à une certaine amélioration du journalisme, avec une diversification de titres et de sujets, le fleurissement de la presse sous le président Khatami met en évidence ses lacunes économiques et professionnelles. Les nouvelles publications manquent de ressources et de personnel qualifié faute d'une formation journalistique institutionnalisée. Évidemment, l'article n'omet pas les convulsions de la presse réformiste avec son déferlement de titres successifs et les répressions de journalistes. Une autre partie est consacrée à l'Internet, nouveau média de publication en Iran. Selon l'A., le journalisme politisé diminue au profit d'un journalisme d'information, une tendance qui mène à un progrès durable de la presse iranienne au niveau de la qualité et du professionnalisme. 
INDEX

Thèmes : 13.1. Iran

\section{AUTEURS}

MARCUS MICHAELSEN

Berlin 